\title{
Gerotopia: Risky Housing for an Ageing Population
}

\author{
CARYL BOSMAN \\ Urban Research Program, Griffith University, , Australia
}

\begin{abstract}
This article explores the influence that baby boomer lifestyle preferences are having on housing landscapes as they enter retirement. The analysis focuses on the emerging phenomenon, in Australia and New Zealand, of Active Adult Lifestyle Communities (AALCs). Using theories of the good life and risk to frame the analysis, I investigate the impacts of AALCs in the USA and provide critical insights into the planning and provision of housing for an ageing population. Research finds that AALCs are marketable commodities and that they also have a positive contribution to make to the health and well-being of residents. However I raise questions in regard to equity concerns and the sustainability of these types of developments.
\end{abstract}

KeY Words: Baby boomers, The good life, Active ageing, Masterplanned communities

\section{Introduction: a Grey Agenda}

It is well established that population ageing is a global phenomenon (Fishman 2010). In America, in 2010, the number of people in the 75-85 cohort was approximately 17 million and this is forecast to grow to over 30 million by 2050 ; with 2.5 million of these being centenarians. The Chinese figures are even more staggering. with 360 million people predicted to be over 60 by 2030 (Unknown 2011). Japan is predicted to have 25 million fewer people by 2015 due to an ageing and depleting population and $40 \%$ of those remaining are forecast be over 55 (Fishman 2010). Like most of the rest of the world, Australia and New Zealand also have an ageing population and baby boomers constitute a significant percentage of the populace in both countries. There are a number of trends/issues related to an ageing population: a reduction in the workforce and an increase in welfare/pension dependence, a change in consumer and lifestyle patterns and most significantly in regard to this paper, the provision of housing.

The official retirement age for many boomers is 65; however, many consider working in some capacity in their retirement and some are opting to retire much 
later (Hamilton \& Hamilton 2006). Indeed, the Australian Federal Government is developing and implementing strategies and incentives for boomers to stay in the workforce longer. The aim of this endeavour is to minimize risks to the economy and labour market, both of which are predicted to be severely impacted by the ageing population. A large percentage of retirees means a reduced number of taxpayers and a greater need for pensions and public health care, all of which will significantly reduce the government's coffers.

10 The first wave of baby boomers are now in their 60 s and many are noted for being experienced and discerning, "black-belt", consumers who typically spend more on leisure and recreation than their younger cohorts. Boomers are also reported to be afraid of ageing and to perceive themselves as being much younger than then actually are. This somewhat misleading perception then influences their 15 choice of lifestyle, house design and retirement location (Hamilton \& Hamilton 2006). In addition, Westerhof \& Barrett (2005:129) found that "feeling younger than one's actual age is related to higher levels of life satisfaction and positive affect and to lower levels of negative affect". Boomers then have a high propensity to experience the good life, however defined. They are reported to have high aver20 age annuity, moderate debt and high levels of homeownership, with four out of five Australian boomers being paid-up homeowners.

It is important to note that not all boomers are wealthy and many, in particular those who were negatively affected by the recent global financial crisis, will be and are struggling to fund their retirement (Rosnick \& Baker 2010). The fall in the 25 housing market has significantly impacted many boomers' ability to realize their housing wealth and to purchase the lifestyle anticipated in retirement. Nonetheless, given the large numbers of boomers embarking upon retirement the effect on the housing industry is significant.

The housing industry is implicated in a number of ways: firstly, many of the

30 houses owned by boomers are in suburban areas which are not conducive to ageing in place (Beer, Faulkner, Baker, Tually, Raftery \& Cutler 2009, Smith 2009, Walters 2005). Secondly, as more boomers place their large family houses on the market with the intention to downsize the housing market will become saturated with upper-end housing products with few consumers with the financial means to pur35 chase them. And thirdly, new types and forms of housing are required to meet the needs of those boomers who choose to relocate in their retirement.

It is this third point that is of particular interest here: the influence that baby boomers' lifestyle preferences will have on housing landscapes as they enter retirement. Some initial reports suggest that the majority of boomers show a preference 40 to age in place, not necessarily in the same house (Beer, Faulkner, Baker, Tually, Raftery \& Cutler 2009). Other reports argue that many boomers indicate their intention to downsize their family home and move to a more convivial and desirable location compatible with their lifestyle aspirations. Murray (2007:95) writes that "For many baby boomers the home is increasingly viewed as an asset and its capi45 tal value as a conduit to a range of ... lifestyle choices. ... The value of consumption and lifestyle have begun to take precedence over the role of the home as anchor of personal identity".

One response to this trend is the emergence, in Australia and New Zealand, of the Active Adult Lifestyle (as opposed to retirement) Community (AALC). AALCs 50 "provide an alternative perspective on the notion of ageing in place ... [and] are intended to be dynamic environments, advocating independent living and a good 
quality of life. In so doing, they have become a serious business..." (Grant 2006:103). Moving into an AALC for some boomers is about "making a transition to a new life ... bypassing and resisting the negative expectations and stereotypes of what growing older is supposedly about" (Grant 2006:102). AALCs have been a feature in the US landscape since the 1950s and this phenomenon has grown in recent years, resulting in notable impacts and implications as outline in this paper.

A desktop analysis investigates the impacts of AALCs, specifically examining some of the planning discourses on these types of development. Three sites of investigation have been selected to ensure data collection has international relevance: Australia, New Zealand and the USA. These sites were chosen because of similarities between socio-economic, ideological and physical housing landscapes. The analysis does not distinguish Australian, New Zealand and US data but rather draws upon common ground and in so doing relates a single narrative.

This paper begins with a definition of AALCs followed by the theoretical framework that looks at concepts of the good life and understandings of risk. This section informs the investigation into the impacts and implications of AALCs. The conclusion draws out the main themes and offers some critical insights into the planning and provision of housing for an ageing population and in doing so advances knowledge of housing for baby boomers.

To date research in this area has tended to focus on the needs of the "older" old $(80+)$, of those with special needs for care and support and for those with limited incomes. This focus, on the poor and socially excluded groups, is common in housing studies with the effect that research into the needs, preferences and experiences of the "younger old" and the comparatively affluent has been neglected. This is backed by a number of geographers and sociologists who have argued that consideration must be given to the middle-class and comparatively wealthy if a full picture of housing markets in total is to be produced. And so our project begins to fill this gap by focusing on AALCs.

\section{Active Adult Lifestyle Communities: What are they?}

AALCs are age segregated masterplanned communities that are designed specifically for retired active adults between the ages of 55 and74 (see Schwarz 2009, Suchman 2001). They are usually niche market developments, targeted at the cashed-up, financially secure, healthy and active baby boomer cohorts. Age restricted communities date back to the 1950s in the USA. According to Blechman (2008) the first documented AALC was in the Arizona desert, USA; affordable housing built for retirees on social security benefits and inspired by the prayer "Do not forsake me, God, when I get old". The development, Youngtown, comprised 125 homes and was completed in 1955. The reason for excluding children from living in the community was to keep taxes low; the exclusion of children meant schooling and other related services did not have to be provided (Blechman 2008).

In 1960 Dell Webb, drawing upon the Youngtown model, introduced "resort retirement living" in his development of Sun City, which by 1977 was home to 40,000 residents (Blechman 2008). The next major US AALC to be developed was The Villages which began to emerge in 1983 and will ultimately house 110,000 residents on 20,000 acres (Blechman 2008). AALCs began to emerge in the Australian 
and New Zealand landscapes in the early 2000. These versions of the American model reflect the local cultural, political and economic patterns of the countries in which they are built.

The retirement village industry in Australia and New Zealand emerged in the 1970 s when it fell largely to state and federal governments, church and other notfor-profit organizations to deliver specific accommodation for the elderly (Simpson $\&$ Cheney 2007). In the 1980s the industry diversified and private, for-profit devel-

10 opers entered into the market to provided retirement accommodation. This market has grown and expanded significantly in the last two decades in line with an increase in demand, by baby boomers, for housing choice and lifestyle options. This has not only produced a range of lucrative economic markets, it has also produced planning policies, funding options and service provision implications for all levels of government.

Our definition of an AALC draws upon some of the elements that characterized the early 1970s Australian and New Zealand retirement villages and responds to McGovern \& Baltins (2002) "Australian typology of retirement villages", Resort Style as summarized in Table 1.

20 As in other types of masterplanned communities, buying into AALCs includes adhering to a suite of stringent covenants; specifically, as already mentioned in regard to a person's age and the length of stay for guests. Guests are required to register their stay with Management and in some developments are issued with a guest identity card which is to be carried with the guest at all times while on the

Table 1. Characteristics of an AALC

Resident characteristics

Services/facilities provided

Level of care available House and allotment type

Development size

Tenure arrangements

Governance

Relationship with financiers

Level of wider community involvement
Financially secure; healthy and active, aged 55-74; age restrictions enforced by property title deed and covenants

Extensive: gated security; club house, indoor/outdoor pools; spa; gymnasium; tennis courts; bowling greens; golf; arts and crafts; workshop and other activities; cinema; library; BBQ facilities; social events coordinator; University of the Third Age

Limited

Small allotment; detached suburban dwelling with 2-4 bedrooms designed to replicate the familiar suburban landscapes from which many of the residents are presumed to hail; more recently tower blocks have been built with all the amenities and facilities of their more suburban siblings

Moderate

Strata Title, Community Title, Loan and License and Leasehold

Private, usually the developer

Owner-occupier; no rentals

Limited as development is largely self contained; depending on the size of the development some smaller AALCs are located adjacent to and are link into golf courses, education facilities and health care providers. Research also suggests that many boomers desire to be active citizens and make a contribution to local communities through volunteering and part time employment (Brodnitizki 2007, Suchman 2001). 
premises. Other covenants include regulation of noise, building design and aesthetics and use and maintenance of public and private open space.

AALCs are generally governed/managed through techniques of self-government and governance structures employ soft technologies rather than hard. That is to say the governance framework focuses on "management" rather than domination; on techniques of government that work upon, subjectify and incite individuals to live the good life. This is largely because the development is required to maximize profits and residents are more likely to respond to coercion and self-regulation than to rules that are enforced by force (Kerby 2008).

This government of the self (Foucault 1997) is an ethical practice because the responsibility for risk management becomes that of the individual rather than that of the government or agency of the government. Residents of AALCs are not forced, nor overtly required, by top-down institutions or organizations to secure the good life, and thus ultimately promote the health and well-being of themselves, the community and the population. Instead residents are incited to take up the responsibility for choosing and managing their own risks around ageing and the production of the good life. Pat O'Malley (1996:197) argues that practices of the self are inherently efficient as "individuals will be driven to greater exertion and enterprise by the need to insure against adverse circumstances - and the more enterprising they are, the better the safety net they can construct.

\section{Understanding the Good Life}

Definitions and understandings of "the good life" abound. Most hark back to ancient Greek philosophy that revolves around maximizing pleasure and minimizing pain. Aristotle aligned the good life with achieving excellence both mentally and morally. In the early part of the 20th century the term "the good life" emerged as a quantifiable standard of living for the family that was taken up by some Modernist town planners such as Le Corbusier and Frank Lloyd Wright (Fischler 2000). Ideas of the good life combined with ideals of community (which has a history of representing the good life) and informed planning techniques that focused largely on the heterosexual family as a unit of government. As the focus of government has mutated over the last 150 years or so from that of the family to that of "the community" (Rose 2000) and now to that of the individual, so understandings of the good life have also changed.

From a focus on a quantifiable standard of living, happiness and identity of the family, the good life became largely associated with the quality of life of the community, determined through processes of consensus and normalization. More recently "the good life" has become linked to 21 st century techniques and processes of capitalism, in this case characterized by the "prudential consumer" (LabiberteRudman 2006), the baby boomer who minimizes risks attached to retirement and thus maximizes sense of security in old age. More recently some social commentators have linked the good life to global sustainability and climate change (Soper 2004, Stampford 2010).

Diener \& Suh (1997) offer three ways of defining the good life:

(1) Religious and normative ideals and morays; this version of the good life does not concern itself with the subjective and the experiential. 
(2) Fulfilment and satisfaction of preferences and choices made in the free market; this version of the good life is concerned with the ability of subjects to purchase goods and products, consumables and commodities that they believe will enhance their quality of life.

(3) And the third version of the good life is based upon personal experience and subjective knowledges; meaning that happiness and contentment are elements in the production of the good life and not commodities to be bought in the free market.

The second definition or version of the good life is the one that is the most applicable to this project; where the production of the good life is seen to be associated

15 with the preferences/choices people make in the free market and the fulfilment of these expectations based on knowledge and fiscal matters. Income and education are frequently used as indicators of societal well-being. Indeed statistics show that educated and informed individuals in the middle to higher end of the economic bracket generally indicate that they have a good quality of life (Diener \& Suh

20 1997). Other factors often used to measure/determine the good life include: mental health, community status, family stability and levels of social participation. These sorts of indicators generally rank high in AALCs and they are the sort of indicators that become more "at risk" as the population ages.

Many governments are currently concerned with measuring well-being and pro-

25 AQ1 moting it in policies, particularly since the recent GFC (Bacon, Brophy, Mguni, Mulgan, \& Shandro 2010). Well-being indicators generally relate to positive affects: feelings of happiness, fulfilment and life satisfaction (subjective well-being) and to physical living conditions (objective well-being). Subjective well-being largely depends upon the individual's personality type and their ability to survive in the

30 world. It is related to individual sense of self-worth, self-esteem and self-happiness; for example if I am happy I am more likely to have a happy outlook and judge others as being happy as well. Importantly, people who feel positive about themselves and are happy are less at risk from disease, strokes, etc. (Gergen \& Gergen \& Gergen 2001-2002) and are more likely to perceive themselves as experiencing the

35 good life. The conversion of well-being indicators and the production of the good life into policy though is a risky practice with significant implications as outlined below.

\section{Understanding Risk}

In this paper I understand risk as a governmental rationality, as a process of calcu-

40 lating the unknown to produce knowledge that will render the unknown knowable and therefore controllable (Dean 1999). I am not interested in investigating the nature of risk itself, but rather the "forms of knowledge, the dominant discourses and expert techniques and institutions that serve to render risk calculable and knowable, bringing it into being" (Lupton, 1999b:6). Risk can only be known through the discourses, practices and techniques that produce it. Risk does not exist in itself - it is not "real" - it is brought into being/produced through and by power/knowledge.

Risk as a technique of government operates at both the macro and micro scales. On the one hand, discourses of risk operate through global technologies and government strategies. There are some well-documented risks attached to climate 
change, property ownership and global financial markets. There are also risks attached to planning policies and building standards. On the other hand, risk discourses operate through everyday informal communication, local networks and cultural practices. The risks attached to the production of the good life are thus multi scalar. In addition risk operates through top down (sovereign) and bottom up (self) governmental strategies.

Risk as a governmental rationality is concerned with change, with possible circumstances or actions which will disrupt and challenge existing norms (Ewald 1990). In relation to the production of the good life and ageing the two norms that are commonly disrupted and challenged relate to Lupton's (1999a) risk regimes of social/community relations ("normal" communities and identities) and place attachment ("normal" suburban and urban landscapes). In the discourses of AALCs a dichotomy is produced between AALCs as being "normal" (the included "us", a high degree of independence and planning and design revolve around targeted needs and desires), low risk and high levels of positive affect - the good life. At the other end of the pole ageing in place is produced as being subject to continual change and uncertainty, a high degree of dependence, high risk and high levels of negative affect - the not so good life.

Drawing on risk as a governmental rationality, Slovic (2010) makes a strong argument for understanding risk as feeling. He explains that risk as feeling is (Slovic 2010:4):

the notion that images, marked by positive and negative affective feelings, guide judgement and decision making. ... That is, in the process of making a judgment or decision, people consult or refer to the positive and negative feelings consciously or unconsciously associated with the mental representation of the task.

If risk is understood as feeling and is concerned with change then subjects make decisions based on the feelings attached to anticipated outcomes, which are informed by particular images. If the anticipated outcome of moving into an AALC is a better quality of life, informed by images of the familiar and of happy people who are just like me, and the affects are positive and pleasant, than the risks associated with such a move will be perceived as being low and manageable. This is backed by literature which suggests that many boomers chose the location for retirement based upon happy holiday experiences and in anticipation of living the good life (Beer, Faulkner, Baker, Tually, Raftery \& Cutler 2009, Suchman 2001). Correlated with this scenario, if the anticipated outcomes of ageing in place are informed by images of loneliness, crime, vulnerability and isolation (a poor quality of life) and the affects are negative and unpleasant then the risk factor will be judged as being high.

By understanding risk as feeling it becomes ontological. The production of risk is spatial, temporal, socio-cultural and historical (Lupton 1999a, 1999b). That is, rationalities of risk are contextual; they have ontological affects. Our prioritization of risk discourses and our management of them produce identities and subjectivities that say something about who we are. Our risk management strategies mostly relate to concerns about our personal health, wealth and well-being. As Lupton (1999a:14) puts it, our decisions about what risk is attached to influences "how we distinguish ourselves and the social groups of which we are 
members from other individuals and groups, how we perceive and experience our bodies, how we spend our money and where we choose to live and work". Our relationship with, and memories, values and meanings - physical and imaginary - of a particular place influences our perception of what is - or is not - a risky landscape.

Risks attached to the production of the good life are thus subjective and subject to change. They are also very powerful motives for a lifestyle change, to secure the good life in retirement and in doing so support the development of AALCs.

\section{Building Gerotopia: an Active, Independent "Risk Free" Community?}

The planning processes and practices intrinsic to the making of AALCs are similar in many respects to those of masterplanned community developments. The major difference is that AALCs are age restricted and the majority of residents are retired.

Policies to promote "ideal retiree" subjectivities (a way of being and acting) are embedded in the planning and development of AALCs. Many of these policies reflect theories of positive ageing that "postpone" the advent of "old age". Theories of positive ageing emerged in the early 2000 in response to the negative stereotype of ageing as "ugly, toothless, sexless, incontinent, senile, confused and helpless..." (Gergen \& Gergen 2001-2002:3-4). Positive ageing theories have been taken up by Australia, New Zealand and USA governments and are reflected in policies as a commodity that must be purchased and as a technique to divest responsibility for ageing onto individuals (Doling and Horsewood 2011). That is, it becomes the responsibility of the individual to manage and age positively, successfully and productively, particularly in retirement.

25 The fact that most residents of AALCs are retired is significant because it suggests that individual status is not a big concern as residents have already achieved recognition for their contribution to the workforce. Suchman (2001:89) writes that: "Gone are the pretensions and status symbols of the corporate world. By retirement, goals have been met and achievements recognized. Many retirees are much more 30 open to self-expression and less rigid in their need to define their place in society." Buying into an AALC then can be a great social equalizer (albeit within a limited socio-economic bracket) as many residents take up new identities in keeping with the good life lifestyle purchased (Suchman 2001).

By buying into a AALC residents are assured that one of "the great things about living [in the development] ... is that everyone's just like you - making their move to a new lifestyle in a secure environment and getting ready for the time of their lives" (Seachange Village 2009). McHugh \& Larson-Keagy (2005) use the term "birds of a feather" to capture the relative homogeneity of people living in developments like AALCs. As such the house and subdivision design in these developments tend to reflect a uniform aesthetic because there is little need for the same level of product diversity found in most masterplanned communities. Also AALCs tend not to make use of cul-de-sacs and narrow snake-like streets. Instead AALC street patterns usually reflect (to some degree) the importance of way finding and of navigating motor vehicles. It is important to note that way finding and cognition abilities decline as people age. The lack of product diversity and the uniform aesthetic common to AALCs potentially impair, rather than promote these abilities. 
The somewhat homogeneous housing landscape and the street pattern are also risk minimization strategies, both physical (for example manoeuvring a motor vehicle) and social (community formation). A residential development where "everyone is just like us" excludes others who are different and whose affects therefore may be negative. Such a person or situation is frequently judged to be a high risk factor which puts at jeopardy the production of the good life and community formation. Most literature confirms that bonds of community are more commonly created between people of similar age, income, values, background and experiences.

The planning and marketing of community, the provision of which is frequently cited by planners and developers as being essential to achieving the health and well-being of individuals, is at the core of AALCs. Ideas of community encapsulate the good life idyll and community relations comprise a significant risk regime. Discourses on the "loss" of community are prolific. They incite anxiety about a demise of morality, of caring relationships and connection to place - gemeinschaft relationships - and thereby, assert the necessity of finding the solution and embracing it, in order to attain fulfilment and obtain health and well-being, the good life.

Research finds that the health and well-being of AALC residents improves significantly within the first year of residency and residents indicate high levels of lifestyle satisfaction. This outcome is attributed to the physical and social planning of AALCs and also to the lack of housing risks associated with ageing in place; principally fear of isolation, crime and risks attached to property (as opposed to house) ownership and maintenance. Significantly the "improvement" in health and wellbeing of AALC residents has been attributed to sense of community (Grant 2006, Walters \& Rosenblatt 2008). Suchman (2001:74-75) explains:

They want to live among their peers: people of similar socioeconomic backgrounds who have shared some of the same life experiences, think the way they do, and are at a stage when they have the time and inclination to enjoy their lives. An AARC [sic] also offers a club like atmosphere that not only "includes us" but "excludes them." Part of the appeal of an AARC [sic] is that it is a controlled environment, where the way of life is safe, consistent, predictable, comfortable, and less rushed and stressful than life in the larger, workaday world.

In AALCs the production of most social networks is inherently positive, as individuals disengage from wider social life to pursue social engagements that reflect individual needs and choices relevant to their time in life. AALCs promise stability, longevity and security in a postmodern world of fragmentation, instability and globalization. It seems that AALCs are the stuff that community relations (and the good life) are made of. There is however, significant literature that condemns community as a social structure because of the "us" and "them" scenarios it perpetuates; things such as social polarization, inequity and social injustice (Young 1990).

In the planning and development of AALCs the production of the good life is primarily concerned with residents living a socially and physically active lifestyle, one in which the "work ethic" of the workforce is replaced with the "busy ethic" of retirement. The relationship between well-being and an active lifestyle is well established and is informed by the literature that tells us about the benefits of being both mentally and physically active (World Health Organization 2002). The literature also warns us of the risks if we do not engage in physical and metal activities: heart 
disease, obesity, memory loss, depression, and dementia, to name a few of the most well known. The World Health Organizations defines active ageing as including social, psychological and physical health, autonomy and independence (World Health Organization 2002). Important ingredients in the production of the good life include independence, living in a secure, stable, "normal" environment (one that minimizes negative affects) and one that also promotes neighbourliness and social interaction. Research clearly indicates that, perhaps not surprisingly, many boomers have a desire to live such a life in retirement (Beer, Faulkner, Baker, Tually, Raftery \& Cutler 2009) and AALCs offer just such a lifestyle.

By contrast most existing suburban landscapes are seen to promote social isolation, fear, boredom, poor physical health and dependence. This is largely due to the lack of infrastructure and accessible amenities and facilities appropriate to the needs and requirements of individuals as they age (Smith 2009, Walters 2005). To quote the Australian demographer Bernard Salt (2010), "there's nothing that should concern a government (at any level) more than a bored baby boomer in the burbs".

To combat risks associated with boredom, loss of health and well-being, planners, developers and managers of AALCs use various techniques and strategies to ensure residents will remain physically and mentally healthy and socially engaged and so live the good life. This is achieved through both self and sovereign forms of government. At one level residents are required, indeed compelled, to engage in modes of self government and to manage personal risks around health and wellbeing by taking regular exercise, eating well and engaging in communal life.

Active and engaged, independent and self-reliant subjects are also produced through a raft of structured activities developed and facilitated by "community officers" employed by the management. In addition to structured activities AALCs promote lifelong learning courses targeted at "learning for pleasure". By these means the mental, social and physical well-being of the individual is enhanced and risks to self, the community and the state minimized. That is, residents of AALCs will not be a burden on family, neighbours, the community or the state. As Katz (2000:136) explains "the decline of the welfare state has encouraged neoliberal policies and 35 market-driven programs to 'empower' older individuals to be active to avoid the stigma and risks of dependency".

The implications of active ageing policies are that "a lower standard of living, inactivity, mandatory retirement, disability, dependency and social isolation are presented as personal risks and challenges, not social issues" (Labiberte-Rudman 2006:193-194). By promoting and regulating active living in the planning and development of AALCs planners and developers are inscribing ethical and disciplinary modes of behaviour into the housing landscapes (Laurian 2006). Many argue that the good life (well-being) must be the intent of policy rather than a possible outcome and that policy has a significant role to play in influencing well-being for all generations and life forms (Bacon, Brophy, Mguni, Mulgan \& Shandro 2010, Fleuret \& Atkinson 2007). Laurian (2006) urges planners and policy makers to reflect upon moral determinisms embedded in active living and positive ageing agendas before writing them into plans and regulations.

\section{Gerotopia as a Discourse of Segregation?}

50 Many existing suburban landscapes in which most boomers live pose significant challenges to all levels of government as suggest earlier in the paper. The insecurities 
that many boomers feel in relation to existing suburban landscapes lead some of them to move into gated and privatized estates like AALCs. As argued above, in the making of AALCs discourses of the good life are produced to maximize positive affects and thereby minimize the risks attached to ageing and living in a challenging suburban environment. The impacts and implications of further fragmenting the urban fabric by developing AALCs as privatized, consumptive landscapes of wellbeing are significant (Blechman 2008, Brodnitzki 2007, Schwarz 2009). Impacts and implications revolve around, among other things: inequity, political concerns, economics and sustainability. Kerby (2008:76) writes: "these emerging private spaces are seen as a reflection of, and a further contribution to, the fragmentation of the city. This is routinely viewed as a profoundly retrograde step, it is seen to be socially divisive, to add to social segregation and to contribute to urban sprawl".

Inequity is written into the residential landscape as affluent retirees move to new AALC developments, which are commonly located on the edges of existing suburban development primarily because of the availability and cost of land and the prerequisite for golf courses. These new developments tend to be more expensive and most are targeted at the middle and upper end of the housing market. They offer residents a secure and stable life filled with sociality, activity, positive affects and low risk factors - the good life. As already established, in this scenario the good life becomes a commodity, purchasable on the free market and only accessible to those who have the money and the inclination/ability to purchase it.

Those boomers who do not have the means or who do not wish to move as they get older, for whatever reason, remain in the older suburban areas. It has already been established that most suburban landscapes lack the amenities and facilities required by and appropriate to the needs of many people as they age. In addition, as money and voting power shift to newer and/or more conducive development areas that are "age friendly" (such as AALCs) some suburban areas may become even more physically and socially isolated for many boomers as they age. As the literature cited above suggest, this outcome is already being made apparent, although in Australia and New Zealand it is unlikely to have the same degree of impact as in the USA.

The other implication with regard to segregated landscapes and AALCs relates to political, personal and governmental structures. As outlined at the beginning of this paper, AALCs employ techniques of government that are concerned with residents doing things for themselves. This mode of government is, potentially, more economic - in terms of time and money - in that it involves local modes of governing. It is often this appeal, of being active in governing personal everyday landscapes, that attracts boomers to move into an AALC. And it is also this appeal that makes these developments attractive to government agencies and developers. Suchman (2001:21) argues that "active adults impose less of a burden on most public services than do residents of other types of developments". This is because residents are (required to be) healthy and most public services are offered privately within the confines of the gates. Also because of the nature of the development and stable tenure of the residents fire and police services are seldom required (Schwarz 2009).

The political structures of AALCs suggest a lifestyle/the good life characterized by low risk factors and high levels of independence. It also suggests potential social disengagement ("us" and "them") and diminished civic responsibility. The negative affects and high risk factors often attributed to those who are different, "them", impacts upon the level of civic engagement undertaken by those who are included, 
"us". Also, in line with popular neoliberal thought, the price paid to purchase the good life potentially reinforces social disengagement and political conservatism.

It has been noted that many baby boomers become more politically active in their retirement as their time is not taken up by employment, family and other concerns related to making a living (Brodnitzki 2007). The impacts of this are evident in the USA, particularly in states and counties where there is a high percentage of baby boomers and AALCs. In these areas the numbers of voters in the over-55 cohorts has been recorded as being significant (up to one third of the total number of voters) and the ramifications have had a noticeable impact on the politics of the county and the structure of local communities (Gottdiener, Collins \& Dickens 2000). The Villages in Florida, for example, is a key "Tea Party" seat and Sarah Palin has visited there on a number of occasions to great acclaim and been given a AQ2 "rock star" reception (see various youtube.com). The State of Florida, which has a higher than average population of over- $55 \mathrm{~s}$, currently has a conservative state government which spends less money on amenities and schools for children than most other states in the USA (Fishman 2010). In this reading the good life becomes the property of those who have the time and inclination to be politically active and to advance causes that reflect personal needs and desires rather than those reflecting more egalitarian motives.

20 The economic impacts and implication of AALCs further aid in segregating the urban landscape. The development of AALCs is attractive to governments because no additional state costs are required for schooling and other child related services. They are also perceived by some governments to herald an increase in volunteers (Brodnitzki 2007) that will be active in supporting and contributing to wider com25 munities. Importantly the development of AALCs has been seen as a means to broaden the tax base and increase the GDP of a local area, through benefits gained from services providers rather than from real estate and housing markets (Brodnitzki 2007). The good life becomes once again embroiled in cost-benefit rationales.

On another tack, many coastal cities are attracting a significant number of retirees, and conflicts between tourism activities and retirement residential landscapes are inevitable. Retirees are less likely to benefit from economic outcomes of tourists and tourism activities because they are not necessarily seeking employment and because they tend not to participate in tourism activities. Also, when tourism is a major component of the GDP most policies and funding will focus on advancing and supporting the industry rather than on the provision of services to address the needs of a particular cohort. This suggests, as others have done, that the development of AALCs offers a viable solution to housing the growing retiree population (Blechman 2008). This is a solution that is not only good for business but is also beneficial to the health and well-being of the residents.

40 But how sustainable is this version of the good life? Location and natural amenity are often not key determinants in the choice of an AALC site. Many are designed on the premise that the private motor vehicle will remain the primary mode of transport. The location and planning of many AALCs contribute to the growing anxiety over suburban sprawl and oil vulnerability (Dodson \& Sipe 2008). And what of climate 45 AQ3 change and future generations? Stampford $(2010: 13,23)$ writes

There can be no solutions to climate change until sustainable conceptions of the good life are developed ... we need to think through our values, integrate those values into our concepts of the good life and then integrate our actions 
as citizens, consumers and investors so that we may, in fact, live sustainable conceptions of the good life.

If this is to be the case and the good life is taken as encompassing the health and well-being of everyday life for everyone and for the ecosystem, then some radical changes need to be made in the design, planning and development of housing landscapes not just for the boomers but for all generations.

The impacts and implications mentioned in this paper, among others, raise some profound questions around the emergence of AALCs: what are the risks attached to commodifying and packaging the good life exclusively for those baby boomers who can and are willing to purchase it? Is it healthy for society as a whole if people are encouraged to live exclusively with others of the same type (whatever that type may be)? It has long been a core belief of planners that diversity or mixed use is generally a good thing, even if zoning has enshrined the segregation of certain land uses in many planning schemes.

\section{Conclusion}

The appeal of the good life, however defined, is embedded in almost all aspects of planning, developing and marketing of the masterplanned community package. This is evident in the making of AALCs, in which ideas of community and the good life are promulgated as commodities designed to appeal specifically to baby boomers. As Walters and Rosenblatt (2008) have identified, the effects of marketing and consumerism are significant in many boomers choice of lifestyle and residential location.

Four of the themes that emerge from this paper include:

- AALCs versus suburbia: Many of the houses owned by boomers are in suburban areas which are not conducive to ageing in place. These suburbs are frequently perceived to be places with high risk factors - the not so good life. By contrast AALCs are planned and designed specifically for the needs of many baby boomers as they enter retirement and are perceived to be places with low risk factors - the good life.

- Shift in mode of government: Boomers have experienced a mutation of government from the welfare state to a neoliberal regime which requires them to be responsible for and to manage their own retirement risks and to age positively, successfully and productively. The development of AALCs is a manifestation of this governmental strategy.

- Active lifestyle: The production of the good life is premised on independence, active recreation, community engagement and mental stimulation; core ingredients of an AALC. An active lifestyle is a strategy to minimize risks attached to ageing; however, policies that specifically target active living often have ethical implications.

- Money matters: Many boomers indicate their preference to purchase a specific retirement lifestyle, one that represents the good life, rather than just a house. To maintain lifestyle preferences, the good life, and to age positively requires the financial means to do so. This has implications for those who (for whatever reason) remain (age) in place. Fulfilment and satisfaction of preferences and choices made in the free market requires not only the financial means but also the knowledge and ability to purchase them. 
AALCs offer visions of an "un-retiring" active lifestyle, a perpetual holiday experience, fun and excitement, within the safety of the "resort". They sell more than just the good life, they sell a place that is both mythical and real; a hetrotopia, a place of assembled qualities without risk; a place where "everyone's just like you". One might identify this residential landscape with "ontological consumerism". AALCs possibly afford opportunities for residents to re-create meaning and purpose in their life; places that are understood ontologically, as habitus, as miraculous and ageless; in short the good life writ large and in permanent ink.

\section{Acknowledgements}

My thanks to the anonymous referees and the editors of this special edition, Keith Jacobs and Ilan Vize, for their support for this research.

\section{References}

AQ4 Atkinson, R. (2010) Community within inequality, Housing, Theory and Society, 27(2), pp. 143-145.

Bacon, N., Brophy, M., Mguni, N., Mulgan, G. \& Shandro, A. (2010) The State of Happiness: Can Public Policy Shape People's Wellbeing and Resilience? (London: The Young Foundation).

Beer, A., Faulkner, D., Baker, E., Tually, S., Raftery, P. \& Cutler, C. (2009) Our Homes, Our Communities: The Aspirations and Expectations of Older People in South Australia (Adelaide: Flinders University report for $\mathrm{ECH})$.

AQ4 Berry, M. (2007) Housing Transitions and Urban Planning for Liveable Homes and Communities in a Future with an Ageing Population: A Background Paper (Melbourne: RMIT University).

Blechman, A. (2008) Leisureville: Adventures in a World without Children (New York: Grove Press).

Brodnitzki, T. (2007) The growth of active adult age-restricted retirement communities in Connecticut. Unpublished Masters thesis, Department of Geography, Central Connecticut State University, Connecticut.

AQ4 Curtis, K. (2010) Housing, the new frontier, Australian Ageing Agenda, Nov/Dec, pp. 39-41.

Dean, M. (1999) Governmentality: Power \& Rule in Modern Society (London: SAGE).

Diener, E. \& Suh, E. (1997) Measuting quality of life: Economic, social, and subjective indicators, Social Indicators Research, 40(1), pp. 189-216.

Dodson, J. \& Sipe, N. (2008) Shocking the suburbs: Urban location, homeownership and oil vulnerability in the Australian city, Housing Studies, 23(3), pp. 377-401.

Doling, J. \& Horsewood, N. (2011) Home ownership and pensions: Causality and the really big tradeoff, Housing, Theory and Society, 28(2), pp. 166-182.

Ewald, F. (1990) Norms, Discipline, and the law, Representations, 30, pp. 138-161.

Fischler, R. (2000) Planning for social betterment: From standard of living to quality of life, in: R. Freestone (Ed.) Urban Planning in a Changing World: The Twentieth Century Experience, pp. 139-157 (London: E \& FN Spon).

Fishman, T. (2010) Shock of the Gray (New York: Scriber).

Foucault, M. (1997) Technologies of the self, in: P. Rabinow (Ed.) Ethics: Subjectivity \& Truth, Essential Works of Foucault 1954-1984, Vol. 1, pp. 223-251 (London: Penguin Books).

Fleuret, S. \& Atkinson, S. (2007) Wellbeing, Health and geography: A critical review and research agenda, New Zealand Geography, 63, pp. 106-118.

Gergen, M. \& Gergen, K. (2001-2002) Positive ageing: New images for a new age, Ageing International, 27(1), pp. 3-23.

Gottdiener, M., Collins, C. \& Dickens, D. (2000) Las Vegas: The Social Production of an All-American City (Malden: Blackwell).

50 Grant, B. (2006) Retirement villages: An alternative form of housing on an ageing landscape, Social Policy Journal of New Zealand, 27, pp. 100-113.

AQ4 Grant, B. (2007) Retiremnent villages: More than enclaves for the aged, Activities, Adaptation \& Aging, 31(2), pp. 37-55.

Hamilton, M. \& Hamilton, C. (2006) Baby Boomers and Retirement: Dreams, Fears and Anxieties (Canberra: The Australia Institute discussion paper Number 89).

Katz, S. (2000) Busy bodies: Activity, ageing, and the management of everyday life, Journal of Aging Studies, 14(2), pp. 135-152. 
Kerby, A. (2008) The production of private space and its implications for urban social relations, Political Geography, 27, pp. 74-95.

Laliberte-Rudman, D. (2006) Shaping the active, autonomous and responsible modern retiree : An analysis of discursive technologies and their links with neo-liberal political rationality, Ageing \& Society, 26(2), pp. 181-201.

Laurian, L. (2006) Planning for active living: Should we support a new moral environmentalism? Planning Theory \& Practice, 7(2), pp. 117-136.

Lupton, D. (1999a) Risk (London: Routledge).

Lupton, D. (Ed.) (1999b) Risk and Sociocultural Theory (Cambridge: Cambridge University Press).

McGovern, S. \& Baltins, E. (2002) The retirement village industry in Australia: Evolution and structure, in: R. Stimson (Ed.) The Retirement Village Industry in Australia: Evolution, Prospects, Challenges, pp. 23-46 (Brisbane: University of Queensland).

McHugh, K. \& Larson-Keagy, E. (2005) These white walls: The dialetic of retirement communities, Journal of Aging Studies, 19, pp. 241-256.

Murray, S. (2007) The ageing of aquarius, Architecture Australia, May/June, pp. 95-98.

O’Malley, P. (1996) Risk and responsibility, in: A. Barry, T. Osborne \& N. Rose (Eds) Foucault \& Political Reason: Liberalism, Neo-Liberalism \& Rationalities of Government, pp. 189-207 (London: UCL Press).

Rose, N. (2000) Community, citizenship, and the third way, American Behavioural Scientist, 43(9), pp. 1395-1411.

Rosnick, D. \& Baker, D. (2010) The impact of the housing crash on the wealth of the baby boom cohorts, Journal of Aging \& Social Policy, 22(2), pp. 117-128.

AQ5 Salt, B. (2010) Cashing in on baby boomer plans. The Australian, Available at http://www.theaustralian.com.au/business/property/cashing-in-on-baby-boomer-plans/story-e6frg9gx-1225828942095

Schwarz, N. (2009) Age-segregated communities in the San Francisco Bay Area, Unpublished Masters Thesis, Universität Wein, Wien.

AQ5 Seachange Village (2009) Available at http://www.seachangegoldcoast.com.au

Simpson, M. \& Cheney, G. (2007) Marketization, participation, and communication within New Zealand retirement villages: A critical-rhetorical and discursive analysis, Discourse and Communication, 1(2), pp. 191-222.

Slovic, P. (2010) The Feeling of Risk: New Perspectives on Risk Perception (London: Earthscan).

Smith, A. (2009) Ageing in Urban Neighbourhoods: Place Attraction and Social Exclusion (Bristol: Policy Press).

Soper, K. (2004) Rethinking the "good life": The consumer as citizen, Capitaliam, Nature, Socialism, 15(3), pp. 111-116.

Stampford, C. (2010) Re-conceiving the good life - the key to sustainable globalisation, Australian Journal of Social Issues, 45(1), pp. 13-24.

Suchman, D. (2001) Developing Active Adult Retirement Communities (Washington, DC: Urban Land Institute).

AQ5 Unknown (2011) Growing old in China: The business of going grey, BBC News, 4 April. Available at http://www.bbc.co.uk/news/business-12573049

Walters, P. (2005) Growing old on the suburban fringe: Master planned communities and planning for diversity, in: Proceedings of the State of Australian Cities, 30 November-2 December, Brisbane.

Walters, P. \& Rosenblatt, T. (2008) Co-operation or copresence? The comforting ideal of community in a master planned estate, Urban Policy and Research, 26(4), pp. 397-413.

Westerhof, G. \& Barrett, A. (2005) Age identy and subjective well-being: A comparison of the United States and Germany, Journal of Gerontology, 60(3), pp. 129-136.

World Health Organization (2002) Active Ageing: A Policy Framework (Geneva: WHO).

Young, I. M. (1990) Justice and the Politics of Difference (Princeton: Princeton University Press). 